\title{
A Comprehensive Online Calculator for Pediatric Endocrinologists: ÇEDD Çözüm/TPEDS Metrics
}

\author{
Korcan Demir ${ }^{1}$, Samim Özen², Ergun Konakçı ${ }^{3}$ Murat Aydın ${ }^{4}$ Feyza Darendeliler ${ }^{5}$ \\ ${ }^{1}$ Dokuz Eylül University Faculty of Medicine, Division of Pediatric Endocrinology, Izmir, Turkey \\ ${ }^{2}$ Ege University Faculty of Medicine, Division of Pediatric Endocrinology, Izmir, Turkey \\ ${ }^{3}$ Ege University Faculty of Medicine, Department of Biostatistics and Medical Informatics, Izmir, Turkey \\ ${ }^{4}$ Ondokuz Mayıs University Faculty of Medicine, Division of Pediatric Endocrinology, Samsun, Turkey \\ ${ }^{5}$ Istanbul University Istanbul Faculty of Medicine, Division of Growth, Development, and Pediatric Endocrinology, Istanbul, Turkey
}

\section{To the Editor,}

Pediatricians need to make many medical calculations during follow-up of both healthy and sick children. This is particularly relevant for pediatric endocrinologists. The World Health Organization (WHO) provides different tools for offline use in order to assess various anthropometric variables (1). Calculators for many specialties are available in Up To Date which requires subscription (2). There have also been a number of promising and inspiring attempts in our country to make such calculations using Excel or other programming language, however, they could not be widely used. We have recently launched an online, freely accessible, computerized, user-friendly, and scientific tool set containing a wide array of formulae in order to meet the needs of pediatric endocrinologists: ÇEDD ÇÖZÜM (www. ceddcozum.com). ÇEDD stands for Çocuk Endokrinolojisi ve Diyabet Derneği, the official society of pediatric endocrinologists in Turkey and ÇÖZÜM means solution. TPEDS stands for Turkish Pediatric Endocrinology and Diabetes Society and METRICS denotes the nature of the online tool. For international use, we chose a simpler and memorable name for the website: www.childmetrics.org.

ÇEDD ÇÖZÜM (TPEDS METRICS) mainly provides assessment of various physical growth variables. On the main page (Auxology), standard deviation (SD) scores and percentile values can be calculated for weight, height, body mass index, and head circumference of children using one of the three reference data: Centers for Disease Control (CDC), Neyzi et al, and the WHO (weight data are present only for children $<10$ years of age) $(3,4,5,6)$. Body surface area is calculated according to Costeff method (7). For target height, firstly, mean of paternal and maternal height was calculated; next, $6.5 \mathrm{~cm}$ was added to and subtracted from that mean value for boys and girls, respectively (8). Estimation of target height SD scores is done by analyzing the calculated target height using the data of the oldest age group available in the selected reference data (WHO: 18 years, Neyzi et al: 19 years, and CDC: 20 years) $(3,4,5,6)$. At the bottom of the results, there are four links to related pages.

- Growth charts: The input can be seen on the relevant charts derived from the selected reference data.

- Results can be seen in text format.

- Further anthropometric assessments: SD scores of upper/ lower segment ratio (for girls between 3-18 years of age and for boys between 2-18 years of age), waist circumference $(<17$ years of age), and sitting height/height ratio (6-17 years of age) are calculated according to Turkish references $(9,10,11,12)$.

- Calculation of predicted adult height can be made using Bayley-Pinneau (for children with $\geq 6$ years of bone age but the extent of difference between chronological and bone age might prevent calculation for some age groups, especially in boys) and Roche-Wainer-Thissen methods (from 1 year of chronological age to 16 years for boys and 14 years for girls) $(13,14)$.

Growth velocity rates and SD scores can be calculated on another page using four reference data including Turkish 
(unpublished Neyzi et al data for boys between 10 and 15 years of age and girls between 8 and 13.5 years of age), American [Baumgartner et al (15): 6-month to 15.5-yearold boys and 6-month to 13.5-year-old girls; Kelly et al (16): 5.5-year to 18.5-year-old boys and 5.5-year to 17.5-year-old girls] and WHO data (for children <24 months) (17). Growth section also includes a page for calculation of SD scores of insulin-like growth factor 1 (IGF-1) and IGF-binding protein-3 levels (generated with chemiluminescence method) using the data from 1-17-year-old healthy Turkish children (18). A tool to estimate growth hormone dose is also available.

Bone section provides an opportunity to calculate SD scores for total L1-L4 areal bone mineral density using the data obtained with dual X-ray absorptiometry from healthy Turkish children between 2 and 18 years of age (19). Tubular excretion of phosphate and calcium can be estimated as well.

Calculations of thyroid volume SD score are made according the two Turkish studies. Data from newborns and older children up to 19 years of age are derived from the reports by Mutlu et al (20) and Aydiner et al (21), respectively. Ovarian volume is estimated according to the following formula: $\mathrm{x}^{*} \mathrm{y}^{*} \mathrm{z} 0.523(22,23)$.

Glucose/insulin ratio, homeostatic model assessment for insulin resistance, and Quick index can be calculated on the Obesity section. Testosterone/dihydrotestosterone and testosterone/androstenedione ratios can be computed on the human chorionic gonadotropin test section. Unit converter is a simple tool for commonly used laboratory variables (24).

SD scores for a given measurement (x) are mainly calculated using LMS data with following formulae: $L \neq 0$, SD score $=\left[(x / M)^{* *} \mathrm{~L}-1\right] / \mathrm{LS}$ or $\mathrm{L}=0$, SD score $=\ln (\mathrm{x} / \mathrm{M}) / \mathrm{S}$ $(3,4,5,6,10,11,12,16,17,25)$. Interpolation by weighted mean is used to obtain $\mathrm{L}, \mathrm{M}$, and $\mathrm{S}$ values at finer intervals that are not provided in the relevant references (26). When no LMS data are present for a variable, SD scores for a given measurement $(\mathrm{x})$ are obtained by the following formula: SD score $=(x-$ mean $) / S D(9,15,18,19,20,21)$. Percentile values corresponding to calculated SD scores are obtained from a standard normal distribution table.

The tool is under protection of our national society, will be kept updated, and will incorporate new features.

\section{Ethics}

Peer-review: Internally peer-reviewed.

\section{Authorship Contributions}

Concept: Korcan Demir, Samim Özen, Ergün Konakçı, Murat
Aydın, Feyza Darendeliler, Design: Korcan Demir, Samim Özen, Ergün Konakçı, Data Collection and Processing: Korcan Demir, Samim Özen, Feyza Darendeliler, Analysis and Interpretation: Korcan Demir, Samim Özen, Murat Aydın, Feyza Darendeliler, Literature Research: Korcan Demir, Samim Özen, Feyza Darendeliler, Writing: Korcan Demir, Samim Özen, Ergün Konakçı, Murat Aydın, Feyza Darendeliler.

Financial Disclosure: The system has been funded by Merck without any reservation or restriction.

\section{References}

1. http://www.who.int/childgrowth/software/en/ (Accessed on March 22, 2017).

2. https://www.uptodate.com/contents/table-of-contents/calculators (Accessed on March 22, 2017).

3. Kuczmarski RJ, Ogden CL, Grummer-Strawn LM, Flegal KM, Guo SS, Wei R, Mei Z, Curtin LR, Roche AF, Johnson CL. CDC growth charts for the United States. Adv Data 2000;314:1-27.

4. Neyzi O, Bundak R, Gökçay G, Günöz H, Furman A, Darendeliler F, Baş F. Reference values for weight, height, head circumference, and body mass index in Turkish children. J Clin Res Pediatr Endocrinol 2015;7:280-293

5. WHO child growth standards: length/height-for-age, weight-for-age, weight-for-length, weight-for-height and body mass index-for-age: methods and development 2006.

6. de Onis M, Onyango AW, Borghi E, Siyam A, Nishidaa C, Siekmann J. Development of a WHO growth reference for school-aged children and adolescents. Bulletin of the World Health Organization 2007;85:660667.

7. Costeff H. A simple empirical formula for calculating approximate surface area in children. Arch Dis Child 1966;41:681-683.

8. Tanner JM, Goldstein H, Whitehouse RH. Standards for children's height at ages 2-9 years allowing for heights of parents. Arch Dis Child 1970;45:755-762.

9. Turan S, Bereket A, Omar A, Berber M, Ozen A, Bekiroglu N. Upper segment/lower segment ratio and armspan-height difference in healthy Turkish children. Acta Paediatr 2005;94:407-413.

10. Bundak R, Bas F, Furman A, Günöz H, Darendeliler F, Saka N, Poyrazoğlu $\mathrm{S}$, Neyzi $\mathrm{O}$. Sitting height and sitting height/height ratio references for Turkish children. Eur J Pediatr 2014;173:861-869. Epub 2014 Jan 9

11. Hatipoglu N, Ozturk A, Mazicioglu MM, Kurtoglu S, Seyhan S, Lokoglu F. Waist circumference percentiles for 7- to 17-year-old Turkish children and adolescents. Eur J Pediatr 2008;167:383-389. Epub 2007 May 9

12. Hatipoglu N, Mazicioglu MM, Poyrazoglu S, Borlu A, Horoz D, Kurtoglu S. Waist circumference percentiles among Turkish children under the age of 6 years. Eur J Pediatr 2013;172:59-69. Epub 2012 Sep 27

13. Post EM, Richman RA. A condensed table for predicting adult stature. J Pediatr 1981;98:440-442.

14. Roche AF, Wainer H, Thissen D. The RWT method for the prediction of adult stature. Pediatrics 1975;56:1027-1033.

15. Baumgartner RN, Roche AF, Himes JH. Incremental growth tables: supplementary to previously published charts. Am J Clin Nutr 1986;43:711-722. 
16. Kelly A, Winer KK, Kalkwarf H, Oberfield SE, Lappe J, Gilsanz V, Zemel BS. Age-based reference ranges for annual height velocity in us children. J Clin Endocrinol Metab 2014;99:2104-2112. Epub 2014 Mar 6

17. WHO Multicentre Growth Reference Study Group. WHO Child Growth Standards: Growth velocity based on weight, length and head circumference: Methods and development. Geneva: World Health Organization, 2009

18. Guven B, Can M, Mungan G, Acıkgoz S. Reference values for serum levels of insulin-like growth factor 1 (IGF-1) and IGF-binding protein 3 (IGFBP-3) in the West Black Sea region of Turkey. Scand J Clin Lab Invest 2013;73:135-140. Epub 2013 Jan 17

19. Goksen D, Darcan S, Coker M, Kose T. Bone mineral density of healthy Turkish children and adolescents. J Clin Densitom 2006;9:84-90. Epub 2006 Mar 27

20. Mutlu M, Karagüzel G, Alıyazicioğlu Y, Eyüpoğlu I, Okten A, Aslan Y. Reference intervals for thyrotropin and thyroid hormones and ultrasonographic thyroid volume during the neonatal period. J Matern Fetal Neonatal Med 2012;25:120-124. Epub 2011 Mar 17
21. Aydıner Ö, Karakoç Aydıner E, Akpınar İ, Turan S, Bereket A. Normative data of thyroid volume-ultrasonographic evaluation of 422 subjects aged 0-55 years. J Clin Res Pediatr Endocrinol 2015;7:98-101.

22. Pavlik EJ, DePriest PD, Gallion HH, Ueland FR, Reedy MB, Kryscio RJ, van Nagell JR Jr. Ovarian volume related to age. Gynecol Oncol 2000;77:410-412.

23. Herter LD, Golendziner E, Flores JA, Becker E Jr, Spritzer PM. Ovarian and uterine sonography in healthy girls between 1 and 13 years old: correlation of findings with age and pubertal status. AJR Am J Roentgenol 2002;178:1531-1536.

24. Ranke MB, Mullis PE. Diagnostics of Endocrine Function in Children and Adolescents. 4th, revised and extended edition. Karger, 2001.

25. Flegal KM, Cole TJ. Construction of LMS parameters for the Centers for Disease Control and Prevention 2000 growth charts. Natl Health Stat Report 2013;1-3.

26. http://www.cdc.gov/growthcharts/percentile_data_files.htm (Accessed on March 22, 2017.) 